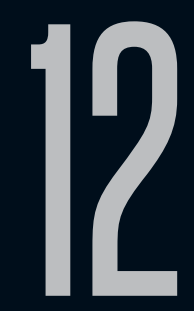

\title{
O CASTELO DE ANDRÉ BRETON: O FANTÁSTICO E O MARAVILHOSO NO SURREALISMO
}

Marta Dantas (UEL)

Recebido em 12 set 2017. Marta Dantas é mestre em História pela Unesp/ Aprovado em 09 out 2017. Assis; doutora em Sociologia pela Unesp/Araraquara; pós-doutora em Literatura pela FFLCH da USP; professora Doutora do Departamento de Arte Visual e do Programa de Pós-Graduação em Letras da Universidade Estadual de Londrina - UEL. E-mail: marta_dantas@hotmail.com.

Resumo: A aventura surrealista é aquela da busca pela liberdade; ela não deve ser tomada como um fim em si mesma, mas como um ponto de partida para o homem, uma iniciação que pretende devolver ao homem tudo aquilo que o império da razão e da lógica nos fez perder; em outras palavras, o Surrealismo se propõe a reencantar a vida. Para tanto, propõe arrancar o homem de si mesmo, recuperá-lo naquilo que nele há de mais profundo e obscuro e despertá-lo para a experiência singular do maravilhoso, numa realidade revelada por meio da descoberta do seu ser múltiplo e da afirmação de sua inquietude. Nessa aventura, a imaginação desempenha um papel fundamental e é uma das vias de acesso ao maravilhoso. Destarte, este artigo visa apresentar como a liberdade, a imaginação, o fantástico e o maravilhoso estão intrinsecamente ligados e, ao fazêlo, esclarecer a própria noção surrealista do maravilhoso. Palavras-chave: Surrealismo; Literatura; Fantástico; Maravilhoso. 


\begin{abstract}
The surreal adventure is the one of the search for freedom; it should not be taken as an end in itself, but as starting point for man, an initiation which seeks to give back to ma all that the empire of reason and logic has made us lose; in other words, Surrealism proposes to r-enchant life. In order to do so, it proposes to take man out of himself, to recover himself in that which is the deepest and most obscure in him, and to awaken him to the unique experience of the marvelous in a reality through the discovery of his multiple being and through the affirmation of his quietude. In this adventure, the imagination plays a key role end it is one of the ways to access the marvelous. Thus, this article aims to present how freedom, imagination, the fantastic and the marvelous are intrinsically linked and, in so doing, clarify the surrealist notion of the marvelous.
\end{abstract}

Keywords: Surrealism; Literature; Fantastic; Marvelous.

\title{
ADENTRANDO O CASTELO
}

O Surrealismo foi um movimento sociopolítico-cultural complexo e amplo, que ultrapassou os limites do campo artístico e literário. É possível escolhermos o ano de 1919-data do surgimento da primeira revista do grupo que se formava em Paris - como seu início; todavia, a morte de André Breton, em 1966, está longe ser o marco do seu fim. O próprio Breton afirmou: o "Surrealismo existia antes de mim e continuará a existir depois de mim" (Apud LIMA, 1995, p.32). Em outras palavras, o Surrealismo "implica aspectos que o antecederam ou o pré-anunciaram, da mesma maneira que implica os desdobramentos do seu sentido e a permanência em nossa atualidade", explica Sérgio Lima (1995, p.7).

Herdeiro natural do Romantismo, cuja poesia, segundo Tristan Tzara (Apud BÉHAR, 1999, p.22), tentou expressar pela primeira 
vez, de maneira consciente, o inefável, o inexprimível, descobriu um verdadeiro "país das maravilhas" inexplorado, repleto de amor por fantasmas e feiticeiras, pelas práticas de magia e ocultistas, pelos sonhos e pela loucura, pela mitologia e pela mistificação, pelas viagens reais e imaginárias, pelo amor ardente, pelas utopias sociais. Coube ao Surrealismo mais do que a exploração desse "país", sua libertação dos entraves impostos pelo racionalismo, pela polícia da boa moral e dos bons costumes, pela filosofia cartesiana e outras tantas formas de repressão, de manutenção de uma imagem convencional do mundo e do seu desencantamento. Todavia, foi também seu herdeiro crítico. Rejeitou o egocentrismo e o sentimentalismo românticos e intensificou outras de suas características como: a valorização da interioridade, a atração pelo mistério, pelo desconhecido e pelo ímpeto revolucionário, imprimindo neles um anarquismo sem precedentes. Também rejeitou o caráter nostálgico e retrospectivo daquele e substitui-o pela aposta na esperança, no desejo e no devir.

O Surrealismo reconhece a antecedência/influência de autores que pertenceram, mas também antecederam e precedem o Romantismo: Dante, Shakespeare, Blake, Walpole, Sade, Poe, Jarry, Roussel, Apollinaire, entre outros e, sobretudo, Nerval, Baudelaire, Rimbaud e Lautréamont. Ele foi também o continuador "da operação sobre a linguagem levada a cabo pelos simbolistas" (LIMA, 1995, p.7), e dos efeitos desorientadores causados pelos objetos, poemas e ações dadaístas e sua indissociação entre vida e $\operatorname{arte}^{1}$. Contudo, representa a superação do niilismo dadá, da

1 A indissociabilidade entre arte e vida faz parte do principal problema a ser superado pela aventura surrealista na conquista da liberdade: o fim das dicotomias. A vida tornada arte colocaria em crise a própria instituição arte/literatura e, consequentemente, a arte 
sua iconoclastia gratuita e de seu anarquismo infantil projetando encontrar formas eficazes de ação para modificar e realidade.

A posição do Surrealismo e "sua ação, sua afirmação, propõe uma ética que resulta da relação do sujeito com o seu próprio desejo e com a prática desta Poesia, vide desta 'produção"' (LIMA, 1995, p.25) e, por isso, deixou um grande legado no campo da literatura e das artes ${ }^{2}$. Todavia, mais do que uma poética, o Surrealismo é uma patética, uma modalidade de viver que adota a imaginação como forma de conhecimento e que atribui ao sonho e a vigília o mesmo estatuto ${ }^{3}$. Essa franca atitude revolucionária e, portanto, transgressiva, se expandiu para além do epicentro francês e do território europeu.

Sua aventura - aquela da busca pela liberdade - não deve ser tomada como um fim, mas como um ponto de partida para o homem, uma iniciação que pretende devolver ao homem tudo aquilo que o império da razão e o reinado da lógica nos fez perder; em outras palavras, o Surrealismo se propõe a reencantar a vida. Para tanto, propõe arrancar o homem de si mesmo, fazê-lo buscar a si mesmo no mais fundo de si e despertá-lo para a manifestação do tenderia a desaparecer na medida em que não mais se oporia à vida. Por isso, a figura isolada de Jacques Vaché, espírito iconoclasta, irreverente, morto prematuramente e que não deixou nenhuma obra para a posteridade, tornou-se um modelo para os surrealistas. 2 Alguns críticos tendem a ver a produção artística e estética surrealista como uma grande contradição do movimento, entretanto, é essa produção plural que impediu o movimento de cair no dogmatismo.

3 Não há como negar a importância das descobertas de Freud para este movimento: "Cumpre sermos gratos às descobertas de Freud" (BRETON, 2001a, p.23); mas a adesão à Freud não foi total. Breton critica a psicanálise freudiana ao questionar seu dualismo (a contraposição entre a realidade psíquica e a realidade material), questiona seu criador por considerar o sonho como exclusivamente a satisfação do desejo e, na contramão da teoria freudiana, propõe uma vida regida por Eros. E embora aprecie o método da psicanálise, Breton pensa que o mesmo não visa outra coisa senão "expulsar o homem de si mesmo" e do qual ele espera "mais do que as meras funções de oficial de justiça" (BRETON, 2007, p.29). 
maravilhoso, "numa realidade revelada, [...] aquela da descoberta do ser e da afirmação de sua inquietude, de sua errância mesma" (LIMA, 1995, p.25).

Nessa aventura, guiada e dinamizada por três vetores capitais - o amor, a poesia e a liberdade -, a imaginação desempenha um papel fundamental e é uma das vias de acesso ao maravilhoso.

Destarte, este artigo visa apresentar como a liberdade, a imaginação e o maravilhoso estão intrinsicamente ligados e, ao fazê-lo, esclarecer a própria noção surrealista do maravilhoso.

\section{NA TORRE MAIS ALTA RESIDE A RAINHA: A IMAGINAÇÃO}

Breton inicia o Manifesto do Surrealismo, de 1924, primeiro documento poético de apresentação do movimento Surrealista ${ }^{4}$, fazendo uma espécie de "diagnóstico" da situação do homem do começo do século $X X$ :

O homem, esse sonhador definitivo, cada dia mais descontente com seu destino, passa penosamente em revista os objetos que foi levado a utilizar, objetos que the vieram ter às mãos por obra de sua indolência ou de seu esforço, visto que ele consentiu em trabalhar [...]. Se alguma lucidez lhe resta, a única coisa que ele pode fazer é voltar-se para a própria infância. (BRETON, 2001, p.15)

E tão importante quanto esse "diagnóstico" é a definição de "homem" como "um sonhador definitivo". Com essa definição, Breton subverte a máxima cartesiana: no lugar do "penso, logo existo", "sonho, logo existo". Todavia, o homem se encontra insatisfeito, abandonado num mundo desencantado, opaco e que

4 Nos referiremos a ele como "primeiro manifesto". 
ameaça sua própria existência. A saída estaria no retorno à infância, na possibilidade de despertar no homem adulto a criança que um dia ele foi. Essa perspectiva, apontada por Breton, tem origem em Baudelaire, que propunha o despertar da infância como condição para o artista moderno porque a criança se interessa pelas coisas banais, prosaicas, "vê tudo como novidade; ela sempre está inebriada"; porque nela, "a sensibilidade ocupa todo o seu ser" (BAUDELAIRE, 1988, p.168-9). Mas o retorno à infância, observa Breton (2001, p.16), não é tarefa simples uma vez que o mundo do trabalho, com o seu pragmatismo, transformou o homem num ser incapaz de experiências excepcionais, como aquelas possíveis pelas vias da imaginação e do amor, porque ele "pertence de corpo e alma a uma imperiosa necessidade prática". Diante de tal situação, o Surrealismo apresenta, em seu primeiro manifesto, seu problema principal, a LIBERDADE, e sua relação, indissociável, com a IMAGINAÇÃO:

A palavra liberdade é a única que ainda me exalta. Considero-a apta a sustentar, infinitamente, o velho fanatismo humano. Ela responde, sem dúvida alguma, a minha única aspiração legítima. No meio de todas as desgraças que herdamos, cumpre reconhecer que nos foi deixada a maior liberdade de espírito. Cabe-nos a nós não fazer mau uso dela. Reduzir a imaginação à condição de escrava [...] seria atraiçoar o supremo imperativo de justiça que se encontra no íntimo de cada um. Somente a imaginação é capaz de mostrar-me aquilo que pode ser. (BRETON, 2001, p.17)

Mais uma vez é Baudelaire quem comparece, agora, na concepção bretoniana de imaginação: a imaginação não é uma faculdade que existe para ser escrava, ela é tão somente "a rainha 
das faculdades" e, portanto, não deve se limitar a copiar, como explica o poeta da vida moderna:

Nestes últimos tempos ouvimos falar de mil maneiras diferentes: "Copie a natureza, copie apenas a natureza. Não há maior prazer nem mais belo triunfo do que uma excelente cópia da natureza". E essa doutrina, inimiga da arte, pretendia ser aplicada não somente à pintura, mas a todas as artes, inclusive ao romance e a poesia. [...] Que misteriosa faculdade é esta rainha das faculdades! Ela alcança todas as outras; excitase e envia-as ao combate. Às vezes se assemelha a outras a ponto de confundir-se com elas, e no entanto ela é sempre a mesma, e os homens que não provoca são facilmente reconhecíveis por não sei que maldição que seca suas produções como a figueira do Evangelho. (BAUDELAIRE, 1988, p.74-75)

A imaginação - longe de se reduzir à capacidade de tornar presente aquilo que está ausente, longe de depender do objeto do qual produziria cópias - é aquela que "constrói a tessitura de apoio por onde transita a razão mediadora, dianoética, entre o sensível e o inteligível, ela própria mescla se sensorialidade e intelecção" (PESSANHA, 1985, p.7), mas não se limita a ser desdobramento da racionalidade habitual. Ela é para os surrealistas, sobretudo, imaginação criadora, fonte por onde jorram novas possibilidades voltada para o por vir. Podemos dizer que, do ponto de vista teórico, Breton posiciona-se como herdeiro da concepção baudelairiana de imaginação e a favor de produções literárias que concedem muito poder a ela. Do ponto de vista prático, somente as criações literárias nascidas do exercício da liberdade, portanto, da imaginação criadora, podem servir à vida na medida em que permitem a libertação das 
obrigações sociais e de uma visão de mundo regida pela lógica e pela razão: "Isadore Ducasse e Arthur Rimabud abrem na poesia uma via totalmente nova ao desafiar sistematicamente todas as maneiras habituais de reagir ao espetáculo do mundo e eles mesmos, se atiraram de cabeça no maravilhoso". (BRETON, 1979b, p.18)

Consequentemente, essas criações alargariam nosso campo de percepção para além do que concebemos como realidade, abririam a possibilidade de a vida poder ser diferente e, por isso, poderiam, até mesmo, alterar nossa práxis vital: "Eu creio que a literatura tende a se tornar, para os modernos, uma máquina potente que substitui, de forma vantajosa, antigas maneiras de pensar ${ }^{5}$ [podemos acrescentar, e de agir]". (BRETON, 1988, p.235)

A partir dessa relação entre literatura e vida, o Surrealismo operou uma revisão de sua história em nome de seus próprios valores. Nesta revisão, a crítica surrealista, sobretudo a bretoniana, recai, de maneira contundente, sobre o romance. Esta crítica tem lugar no decurso de uma longa querela que coincide com a existência do gênero na literatura ocidental moderna, afinal, o primeiro romance moderno, Dom Quixote, de Cervantes, é um romance contra o romanesco (CHENIEUX-GENDRON, 2014). Mas a reação surrealista contra o romance tem endereço certo: o romance Realista e suas variações, como o Naturalismo6: "Os dias seguintes do Naturalismo assistiram uma enorme onda de críticas em todas as direções, cuja última é o ataque surrealista" (CHENIEUX-GENDRON, 2014, p.15).

5 Todas as traduções são de minha autoria.

6 Os ataques surrealistas contra o romance estão expressos em vários de textos, mais enfaticamente em duas as fontes de autoria de André Breton: o Manifesto do Surrealismo, de 1924, e no relato surrealista Nadja, escrito em 1927 e publicado pela primeira vez em 1928. 
As palavras de ordem de Karl Marx e Arthur Rimbaud, respectivamente, "transformar o mundo", "mudar a vida", são também aquelas do Surrealismo. É compreensível, portanto, que a crítica recaia sobre o romance realista:

\begin{abstract}
"Breton condenava o romance porque o tomava como uma anedota submetida ao império da lógica e cujo objeto é exterior ao sujeito que escreve, e porque, nele, todo caráter humano é coerente e determinado [...]. Era da opinião de que os romances, 'livros ridículos que insultam a inteligência', nasceram da atitude realista inspirada no positivismo, e empenhavam-se 'em adular o gosto mais reles do público'. (BRETON, 2001, p.19), o que explicava a popularidade do gênero" (DANTAS, 2008, p.82)
\end{abstract}

A crítica bretoniana sobre o romance não é simplesmente mais uma das vozes da querela da época; o romance foi objeto de debate constante no movimento por uma razão muito importante: "ele solicita a questão do julgamento de realidade e do julgamento de possibilidade" (CHENIEUX-GENDRON, 2014, p.31). Em muitos romances os personagens são como fantoches forjados pelo autor e não escondem a pobreza da imaginação romanesca. Assim,

o Manifesto acusa o autor do romance de definir o caráter dos personagens e atribuir ao herói ações e reações previstas; os personagens seriam seres humanos formatados, pois o autor desconheceria a diversidade da vida, sua ampla gama de tons, de sons e de sabores. (DANTAS, 2008, p.76)

Podemos dizer que o romance de influência positivista apresenta uma realidade opaca, pobre, uma vez que seus personagens estão submetidos à imperiosa necessidade prática, a uma trama 
determinista, irreversível e submetida ao princípio de realidade. A impotência dos personagens diante de uma vida determinista não alimentaria no leitor a vontade de transformação da realidade, da vida e de si mesmo. Além disso, por meio da ficção romanesca, o autor e o leitor se contentariam em "delegar aos personagens de papel seu desejo de mudar a vida e o mundo" (MORRIER-CASILE, 1994, p.120).

Nos julgamentos de Breton não participam critérios de ordem estética e técnica; eles pressupõem uma posição ética: o destino do homem. Isso explica seu desinteresse pelas categorias literárias e as distinções de gêneros. Todavia, a originalidade da crítica surrealista contra o romance realista consiste na denúncia de sua pretensão psicológica de oferecer uma imagem unificada e coerente de seus personagens, uma grade psicológica simplista que não dá conta da complexidade, da profundidade e multiplicidade do ser humano irredutivel a qualquer forma de positivismo:

Da unidade de corpos nós nos apressamos em inferir à unidade da alma, ao passo que nós abrigamos múltiplas consciências e que o voto destas é muito capaz de depositar em nós o empate entre duas ideias opostas. (BRETON, 1988, p.234)

No Segundo Manifesto do Surrealismo, de 1930, Breton é contundente; "empate entre ideais opostas" é a grande motivação que guia o movimento:

Tudo nos leva a crer que existe um certo ponto do espírito de onde a vida e a morte, o real e o imaginário, a passado e o futuro, o comunicável e o incomunicável, o alto e o baixo deixam de ser percebidos como contraditórios. Ora, seria falso 
atribuir à atividade surrealista qualquer motivação que não fosse a esperança de determinar esse ponto. (2001, p.153-154)

Encontrar esse ponto onde o real e o imaginário (e todas as outras dicotomias) deixam de ser compreendidos como contraditórios, é reviver, ainda que de forma fugaz, a infância. Portanto, a "mente que mergulha no surrealismo revive com exaltação a melhor parte da própria infância" (BRETON, 2001, p.56).

Fica claro que o problema para Breton não é o romance enquanto gênero, mas determinadas produções literárias que contribuem com a opacidade da realidade, que guiam seus personagens por meio da coleira do determinismo e sua trama por meio do princípio de verossimilhança: "Uma obra de arte digna deste nome é aquela que nos faz reencontrar o frescor de emoção da infância" (BRETON, 1979, p.23). E no movimento para reencontrar o "frescor da infância", os surrealistas reabilitaram e renovaram o maravilhoso.

\section{FANTÁSTICO! O MARAVILHOSO ESTÁ POR TODA PARTE}

Segundo Béhar (1999), a bandeira do maravilhoso foi fincada, primeiramente, nas produções das crianças, dos loucos e dos "primitivos". Para Breton, as criações artísticas desses três grupos eram manifestações do maravilhoso. Ele dedicou maior atenção aos mecanismos da criação da arte feita pelos loucos porque estes estariam libertos de todos os entraves e, justamente por isso, suas produções traziam consigo a "chave" que daria acesso a outros "campos" (BRETON, 1979c). Quanto aos "primitivos", o maravilhoso se manifestaria na sua forma de pensar, como explica Benjamin Péret na sua Antologia de mitos, lendas e contos populares da 
América, publicado em de 1942: "Podemos assegurar que as explicações que o primitivo dá sobre a origem do mundo e a sua própria são produtos da imaginação pura onde a parte da reflexão consciente fica nula ou quase [...] estas criações pertencem, quase sempre, ao maravilhoso poético" (Apud BÉHAR, 1999, p.21).

Embora o termo "maravilhoso" esteja presente em vários textos, de naturezas diversas, de autoria dos surrealistas, na maioria das vezes, ele é vago; ora equivale a fantástico, ora a poesia, ora a surrealidade. E embora Breton não tenha definido e nem teorizado sobre o maravilhoso, coube, sobretudo a ele, dar um novo vigor e um conteúdo particular ao termo.

No primeiro manifesto, a crítica ao romance realista é sucedida pelo elogio ao maravilhoso.

De momento, minha intenção era denunciar o ódio ao maravilhoso que grassa no espírito de certos indivíduos e o ridículo de que querem cobri-lo. Digamo-lo claramente e de uma vez por todas: o maravilhoso é sempre belo, qualquer tipo de maravilhoso é belo, somente o maravilhoso é belo. (BRETON, 2001, p.28)

O maravilhoso é tão crucial que, na visão do poeta surrealista, somente ele "é capaz de fecundar as obras pertencentes a um gênero inferior, como o romance e, de modo geral, tudo o que participa do gênero narrativo" (BRETON, 2001, p.29). Breton toma como exemplo o romance gótico, mais especificamente $O$ Monge (1795), do inglês Matthew Gregory Lewis (1775-1818):

O Monge, de Lewis, prova-o admiravelmente. 0 sopro do maravilhoso penetra-o de todo em todo. [...] este livro exalta apenas, do começo ao fim e da 
maneira mais pura que se possa conceber, aquela parte do espírito que aspira a desprender-se da terra. (2001, p.29)

O Monge é uma história de fantasma valorizada por Breton porque nela o terror sobrenatural, o erotismo e a violência se exprimem livremente e se inserem perfeitamente no real enquanto "as aspirações [das personagens] desempenham um papel lógico, uma vez que o espírito crítico não se apropria delas para contestálas" (BRETON, 2001, p.29). Romances, como o de Lewis, construídos pelas tramas de inverossimilhanças, onde o medo, os acasos e a atração pelo insólito comparecem como recursos "para os quais nunca se apelará em vão" (BRETON, 2001, p.30), são importantes uma vez que expressam a irremediável inquietação humana. Por outro lado, Breton condena aqueles que «não serve[m] para dinamizar a energia obscura em trabalho no coração do real, capaz de subvertê-lo, de operar um movimento» (BONNET, 1975, p.341342). Grosso modo, poderíamos dizer que ele julga romances, contos, enfim, toda sorte de produção literária (e artística) a partir da seguinte sentença: em que medida elas nos lançam para fora do tecido coerente e contínuo do cotidiano, do habitual e nos faz emergir num estado de imensa perplexidade. Sobretudo nas produções literárias, é a presença do imprevisto, muitas vezes sob o traje do insólito, que se faz necessária, pois ele é um dos recursos capazes de abrir uma fenda na trama do que é previsto. Tal posicionamento vem ao encontro de uma das possibilidades de definição de fantástico como uma ruptura da ordem estabelecida, como um efeito de hesitação provocado no leitor diante de um acontecimento sobrenatural7. Sobre O Monge, Breton conclui: "uma

7 Vale lembrarmos que tal definição, embora muito próxima àquela de Tzvetan Todorov 
vez desembaraçado de uma parte mínima do enredo romanesco, tributário da moda de seu tempo, converte-se-à num modelo de precisão e inocente grandeza" (2001, p.29). Uma nota de rodapé logo após a palavra "grandeza" é, para o propósito deste breve estudo, muito importante: "O que é admirável no fantástico é que não há mais fantástico: só há o real" (p.365). Nessa nota, Breton sinaliza o que, do ponto de vista surrealista, é o maravilhoso.

Em um dos dicionários em voga no final do século XIX, o Dicionário da língua francesa, de Émile Maximilien Paul Littré, o maravilhoso é definido como "a intervenção de seres sobrenaturais como deuses, anjos, demônios, gênios, fadas, em poemas e outras obras da imaginação" (Apud BÉHAR, 1999, p.16). Todavia, segundo Breton, o maravilhoso

varia de época para época; ele participa, misteriosamente, de uma espécie de revelação geral de que só nos chegam os pormenores: as ruínas românticas, o manequim moderno ou qualquer outro símbolo apto a mexer com a sensibilidade humana por algum tempo. (2001, p.30)

Breton reconhece que o maravilhoso se manifesta, diferentemente, nas histórias mitológicas, nos contos de fada, nas criações românticas, nos romances góticos, porque correspondem a épocas diferentes, mas em todas elas encontramos a presença irremediável da inquietação humana. Para os surrealistas, o homem

(2014), provém (provavelmente) de Charlie Nodier, romancista e autor do ensaio "Du Fantastique en littérature", de 1830. Nodier pertencia ao círculo de escritores lidos pelos surrealistas e, embora seja considerado o precursor das reflexões teóricas acerca do fantástico, seus textos apresentam certa confusão terminológica uma vez que os termos "fantástico" e "maravilhoso" são, muitas vezes, utilizados indiferentemente. A falta de precisão entre os termos também é constatada em textos de autoria dos surrealistas, todavia, esclarecermos porque o termo "fantástico" é preterido em relação ao "maravilhoso". 
moderno não crê (ou não deveria crer) mais em Deus, em fantasmas, em milagres e toda sorte de "manifestações sobrenaturais" porque todas essas "manifestações" teriam origem na imaginação dos homens. A definição de Littré, portanto, já não contempla o espírito e a vida do homem moderno. Haveria, portanto, um maravilhoso condizente com o homem do século XX. "Que seja nas civilizações arcaicas ou na literatura do século XIX, os surrealistas esperam o dia de um maravilhoso mais operatório" (BÉHAR, 1999, p.24).

No final doano de 1925, um dosintegrantes doSurrealismo, o então jovem Michel Leiris, foi incumbido de redigir um glossário completo sobre o maravilhoso para o Burreau de Recherches surrealistas. Esse foi um esforço ambicioso de definir o maravilhoso visando, de um lado, o projeto surrealista e seus autores fundamentais, e do outro, a teorização, no campo literário, de Nodier e outros autores que, antes mesmo que Leiris, abordaram o fantástico e o maravilhoso. O projeto do glossário terminou por tomar a forma de um Ensaio sobre o Maravilhoso, mas ele jamais foi finalizado e o conjunto dos manuscritos terminou recebendo o título de Fragmentos de um ensaio sobre o maravilhoso ${ }^{8}$. Em Fragmentos..., o maravilhoso pertence ao domínio da literatura ${ }^{9}$, meio ideal, segundo Leiris (Apud,

8 Insatisfeito com o resultado desse trabalho, Leiris jamais levou a cabo sua publicação. Seus manuscritos, conservados na Biblioteca Jacques-Doucet, em Paris, foram intitulados Fragmentos de um ensaio sobre o maravilhoso e só vieram a público no ano 2000; eles contêm dois textos principais: "Fragmentos de um ensaio sobre o Maravilhoso" e "O Maravilhoso 'moderno"'. Neste artigo, estamos nos referindo apenas a estes fragmentos.

9 A reflexão de Leiris sobre o maravilhoso não se esgota em Fragmentos..., ela participa de toda sua trajetória e está presente em obras posteriores. Embora a noção de maravilhoso em Leiris não seja nosso objeto, o estudo de Collani (2007) e NatsumeDubé (1995) indicam o deslocamento, com o passar dos anos, do campo estritamente literário para a reflexão do maravilhoso na vida e sua necessidade de comunicação por meio da escrita: "encontrar as fontes do maravilhoso [...] na 'realidade nua' da vida a mais ordinária" (LEIRIS, Apud NATSUME-DUBÉ, 1995, p.120); "a comunicabilidade do 
COLLANI, 2007, p.26), para subverter as relações lógicas, e cujo exemplo capital seria aquele que se já se apresentava no movimento surrealista: o maravilhoso é "a parte mais atual do surrealismo" e ele evoca a "surrealidade". Leiris embarca numa reflexão sobre o homem e seu poder imaginativo e nega toda e qualquer intervenção exterior ao homem. A negação da transcendência coloca a realidade e a irrealidade no mesmo nível e, uma vez que tudo imana do homem, a própria transcendência é profanada. Ele desvela o maravilhoso moderno e, ao fazê-lo, traz à tona aspectos da noção do maravilhoso no Surrealismo: ele se manifesta como algo que se opõe à lógica ou que perturba a causalidade lógica como o acaso, o encontro fortuito de realidade distantes; ele nos acompanha na "descida aos infernos", ou seja, no mais profundo de nós mesmos, tendo como exemplo máximo Aurélia de Nerval; e o nominalismo ${ }^{10}$, cujos exemplos, se encontram sobretudo em Rimbaud, Lautréamont, também é considerado uma outra forma de acesso ao maravilhoso. Enfim, todas as formas de acesso e manifestação do maravilhoso estariam intimamente ligadas à imaginação, pois caberia a ela encontrar o maravilhoso, não importa onde, uma vez que ele seria, sempre, uma projeção do mundo interior do homem. Enfim, o esforço de Leiris, que a princípio era definir o que seria o maravilhoso enquanto gênero literário, levou-o a concluir sobre a impossibilidade de defini-lo uma vez que "o maravilhoso só existe no interior do homem" (Apud, COLLANI, 2007 p.31).

Maravilhoso, a última condição necessária para sua plena realização na medida que ela seja compartilhada ao ponto de sair do quadro individual" (LEIRIS, Apud NATSUMEDUBÉ, 1995, p.121).

10 Leiris explica o que entende por "nominalismo" em sua obra L'homme sans honneur (apud NATSUME-DUBÉ, 1995, p.111): " "Nominalismo» à maneira que eu entendia quando eu era surrealista: nenhuma outra realidade que a das palavras; o mundo ordenado pelo discurso". 
Enquanto Leiris tentava definir o maravilhoso, Breton, que privilegiava a vida em detrimento da teoria, estava experimentando e investigando o mesmo na vida, decorre daí a ausência de conceituação de sua parte acerca do maravilhoso embora ele esteja muito presente em sua obra. E em 1962, no prefácio que escreveu para o livro de Pierre Mabille, Le miroir du merveilleux, Breton admitiria que este foi quem melhor o definiu contrapondo-o, claramente, ao fantástico:

O maravilhoso, ninguém conseguiu defini-lo melhor [que Mabille] por oposição ao "fantástico" que tende, infelizmente, cada vez mais a suplantá-lo junto a nossos contemporâneos. É que o fantástico, quase sempre, pertence à ordem da ficção sem consequência, enquanto o maravilhoso brilha na ponta extrema do movimento vital e envolve em si, inteiramente, toda a afetividade. (Apud, WILLER, 2008, p.328)

Uma vez que o maravilhoso é tido como imanente à vida e ao próprio homem, uma vez que não é mais tido como manifestação do transcendente, o "admirável no fantástico é que não há mais fantástico". Nesta perspectiva surrealista, o fantástico perde sua razão de ser uma vez que sua existência depende de sua oposição à ordem do "mundo real", de uma concepção transcendental do maravilhoso em oposição à vida real. Para Breton, como também para Mabille, o maravilhoso além de ser um evento imanente à própria vida e, portanto, atemporal, desvela uma espécie de ordem oculta da vida: "O homem percebe, nos fenômenos da natureza, uma ordem na qual ele se insere e da qual ele participa; ele percebe uma regra escondida" (MABILLE, 1946, p.26). Ele é a capacidade de renovação comum a todos os homens e "provavelmente a só 
realidade que conserva a esperança no homem e no seu futuro" (MABILLE, 1946, p.91-92). Mabille aposta na potência atribuída por Breton à imaginação: "É a imaginação que tende a se tornar real" (MABILLE, 1946, p.71).

O maravilhoso, para Breton, não se trata, portanto, de um gênero ou subgênero da literatura, mas de um evento que irrompe na vida e a transtorna, como ele relata, Nadja (2007), Amor louco (1971) e Arcano $17(1986)^{11}$; trilogia que atesta que

o maravilhoso está por todo lado. Compreendido nas coisas, ele se manifesta logo que conseguimos penetrar não importa qual objeto. [...] 0 maravilhoso está ainda entre as coisas, entre os seres, neste espaço onde nossos sentidos não o percebem diretamente, mas somente se enchem de energias, de ondas, de forças [...], onde se elaboram equilíbrios efêmeros, onde se preparam todas as transformações. (MABILLE, 2002, p.230)

O pensamento de Mabille se situa no cruzamento entre seus conhecimentos antropológicos, sociológicos, médicos, e sua adesão ao hermetismo, muito próximo, portanto, à formação do pensamento de Breton. Todavia, não é Mabille quem ilumina a noção do maravilhoso para os surrealistas, ao contrário, o Surrealismo teve papel relevante para o pensamento de Mabille; seu mérito foi dedicar duas obras, ao trabalho de escuta poética do maravilhoso ${ }^{12}$ visando elucidá-lo a partir da perspectiva surrealista.

Podemos dizer que a noção do maravilhoso para Breton ultrapassou o limite temporal da concepção do "maravilhoso moderno" de Leiris, ultrapassou os limites do texto literário,

11 Estas obras foram publicadas pela primeira vez, respectivamente, em 1928, 1937, e 1947.

12 São elas: Le mirroir du merveilleux (1940) e Le merveilleux (1946). 
abraçou a vida. Ela se tornou aquilo que justamente ultrapassa as contingências temporais e geográficas - porque está intimamente ligada à inquietação humana, ao inefável - e abre o caminho para a surrealidade. O maravilhoso no Surrealismo exprime, portanto, a necessidade de ultrapassar limites do tempo, do espaço, de destruir todas as barreiras. Ele "é a luta da liberdade contra tudo que a reduz, a destrói e a mutila; ele é [...] qualquer coisa de diferente do trabalho regular e maquinal: tensão passional e poética" (MABILLE, 1946, p.69). Portanto, ele é fundamental na aventura humana em busca da liberdade.

\section{O CASTELO DE BRETON}

Por hoje estou pensando num castelo cuja metade não está, necessariamente, em ruínas; este castelo me pertence, visualizo-o num recanto agreste, não muito longe de Paris. Suas dependências são inumeráveis e, no que respeita ao interior, ele foi terrivelmente restaurado, de sorte que nada ficasse a desejar em matéria de conforto. [...] 0 espírito de desmoralização fixou residência no castelo [...]. Ao fim e ao cabo, o essencial não consistirá em sermos senhores de nós mesmos [...]? (BRETON, 2001, p.31-32)

O castelo, descrito por Breton, abriga o "sonho" surrealista.

Suas ruínas estão carregadas de significação na medida em que

exprimem, visualmente, o colapso do período feudal; o fantasma inevitável que os assombra, marca, com uma intensidade particular, a apreensão do retorno das potências do passado; as passagens subterrâneas descrevem um percurso lento, perigoso e obscuro do indivíduo humano em direção ao dia [...]. É sobre este fundo caloroso que escolhem aparecer os seres de tentação pura, 
incarnando o mais alto grau da luta entre, de uma parte, o instinto de morte que é também, como mostrou Freud, instinto de conservação e, de outra parte, Eros que exige, depois de toda ruína humana, que seja feita reparação resplandecente da vida. (BRETON, 1979b, p.22-23)

Ninguém melhor que o próprio Breton soube explicar o quão cara é a literatura gótica para o Surrealismo:

Nenhuma tentativa de intimidação nos fará renunciar a tarefa que nós nos impomos [...] a elaboração do mito coletivo próprio a nossa época do mesmo modo que [...] o gênero "noir" deve ser considerado como traço patológico da grande perturbação social que dominou a Europa no final do século XVIII. Não é sem interesse observar que a iniciação desse [...] gênero foi atribuída, em 1764, por Horace de Walpole [...] A gênese de uma tal obra [O castelo de Otranto] [...] coloca efetivamente em causa nada menos que o método surrealista. (1979b, p.23-24)

No excerto acima, Breton não só sugere que o Surrealismo deveria ser, como a literatura gótica fora outrora, um "traço" de sua época; ele vai mais longe, reconhece a prática do "método surrealista" no processo de criação de 0 castelo de Otranto abandonar-se ao sonho e a escrita automática - antes mesmo do Surrealismo, por meio do relato do próprio Horace Walpole em uma correspondência a William Cole:

Quer que eu conte a origem deste romance? Numa manhã, [...] eu acordei depois de um sonho, e tudo o que eu pude me lembrar é que eu me encontrava dentro de um velho castelo (sonho muito natural para um espírito preenchido, como estava o meu, 
de «romance» gótico). Sobre a rampa a mais elevada de uma grande escada, eu vi uma gigantesca mão revestida de uma armadura. Naquela mesma noite, me sentei e comecei a escrever, sem saber o que eu ía dizer ou contar. Em suma, eu estava tão absorvido pelo minha narrativa (terminada em menos de três meses) que numa noite eu escrevi desde [...] seis horas da noite, até uma hora e meia da manhã quando meus dedos estavam tão fatigados que não pude mais segurar a pena (Apud BRETON, 1979b, p.24).

A experiência da escrita automática é mais uma maneira de acessar o maravilhoso. Daí recorre sua importância a ponto de, no primeiro manifesto, Breton definir o Surrealismo como "automatismo psíquico em estado puro mediante o qual se propõe exprimir [...] o funcionamento do pensamento. Ditado do pensamento, suspenso de qualquer controle exercido pela razão, alheio a qualquer preocupação estética ou moral". (2001, p.40)

A questão do automatismo gerou muita polêmica no interior do movimento. Sabemos que não existe escrita automática pura. O que a anedota indica - Breton poderia nos oferecer outros exemplos - é a existência de "qualquer coisa de universal, talvez inerente à própria criação poética, naquilo que surrealistas denominam de escrita automática" (WILLER, 2008, p.712). O que caracteriza a escrita automática, como explica Willer, "é a experiência da dissociação", ou seja, a separação entre a consciência de quem escreve e o que está escrito. Todavia, a escrita automática almejada pelos surrealistas "corresponde às situações em que palavras, imagens, sintagmas, são percebidos como entidades com existência objetiva, [...] antes, no momento da criação, durante o 
processo, e não só depois do texto haver sido escrito" (WILLER, 2008, p.713). Não se trata de uma experiência de perda da consciência, "mas de ampliação, hiperconsciência" (WILLER, 2008, p.713). A escrita automática é expressão da consciência do duplo; implica na objetivação do sujeito e na subjetivação do objeto; ela expressa conteúdos pré-conscientes e é, portanto, a confirmação da constatação de Rimbaud e Nerval de que "eu é um outro" e sua retificação: "esse 'outro', por sua vez, é eu” (WILLER, 2008, p.716). A escrita automática, porque promove uma forma singular de alterações da consciência associadas à criação, foi considerada pelos surrealistas como análoga às iluminações, às revelações, aos êxtases e, portanto, como grande via de acesso ao maravilhoso.

Quanto ao castelo, ele é um lugar e uma imagem que, aos olhos de Breton (1979b, p.25), parece favorável à recepção de grandes ondas que anunciam algo que imobiliza o indivíduo, mas que também pode ativar sua solução. O psiquismo humano encontrou no castelo gótico aquilo que há nele de mais universal e, por isso, a "necessidade de saber o que é para nossa época equivalente de um tal lugar". Breton reconhece que o Surrealismo não encontrou um novo lugar, porém, constatou que da época do romance noir até aquele momento, primeiras décadas do século $X X$, mudanças ocorreram no comportamento: o homem moderno, "assombrado" pelas coincidências da vida e pelas aparições que transtornam a compreensão lógico-racional, deixa-se levar, muito mais do que o de outras épocas, em direção ao desconhecido, entrega-se a ele. E é justamente essa mudança de comportamento que, constata Breton, explicaria a internacionalização do Surrealismo, e sua tendência à criação do mito coletivo. 
No castelo de Breton habitavam senhores sem súditos, senhores de si mesmos e não de outrem. Na sua metade restaurada, a arquitetura de feições modernistas possui muito conforto e abriga espíritos radicalmente inconformistas e sedentos de desmoralização, seguidores do Marquês de Sade, que foi proprietário de um castelo em Lacoste, na França, no final do século XVIII, e preencheu seus espaços, real e virtualmente, com práticas eróticas libertinas. As portas do castelo estão sempre abertas na esperança que outros nele se aventurem. O mais importante: "Quando lá estamos, vivemos, realmente, de nossas fantasias" (BRETON, 2001, p.32).

Enquanto na narrativa gótica o castelo é um espaço fechado, escuro e isolado onde um imaginário sombrio e assombrado por fantasmas se manifesta, o castelo de Breton se localizaria num "recanto agreste, não muito longe de Paris" (BRETON, 2001, p.31) e os fantasmas que lá se manifestam não vêm do além; eles dizem respeito ao processo de autoconhecimento. A problematização do fantasma no Surrealismo, ou seja, daquele que nos habita, possui tamanha importância que abre a primeira página de Nadja (2007):

Quem sou? Se excepcionalmente recorresse a um adágio, tudo não se resumiria em saber "com quem ando"? Devo confessar que essa expressão que perturba um pouco, pois dendê estabelecer entre mim e certos seres relações mais singulares, [...] mais perturbadoras [...]. Diz muito mais do que quer dizer, me faz desempenhar em vida o papel de um fantasma, alude evidentemente ao que eu deveria deixar de ser para ser quem sou. [...], dá-me a entender que tudo o que considero manifestações objetivas de minha existência [...], passa [...] de 
uma atividade cujo verdadeiro campo permanece desconhecido para mim. A representação eu tenho do "fantasma", [...] vale [...], para mim, como a imagem acabada de um tormento que pode ser eterno. (BRETON, 2007, p.21)

Destarte, a imagem do castelo pode ter, entre outras, a dimensão simbólica do nosso próprio corpo psíquico ${ }^{13}$, lugar onde devemos nos aventurar, explorar seus mais diversos espaços, do alto da torre até as suas catacumbas, em busca de nós mesmos e correndo o risco de só nos depararmos com o nosso próprio fantasma:

lembremos-nos de que a ideia surrealista visa, simplesmente, a recuperação total de nossa força psíquica por um meio que mais não é do que a descida vertiginosa ao interior de nós mesmos, a iluminação sistemática de lugares ocultos [...], - passeio perpétuo em plena zona proibida. (BRETON, 2001, p.166)

\section{NO CAMINHO DO CASTELO: O ENCONTRO DE BRETON COM NADJA}

O "passeio pela zona proibida" é processo de autoconhecimento e ação libertadora. Ele implica num primeiro "passo" (não no sentido metafórico), não na direção do divã do psicanalista ou na do banco do confessionário, mas um passo sem rumo, seguido de outros, pelas ruas da cidade. Nadja (2007) é, entre outras coisas, o relato desse processo, da experiência de um Breton disponível ao acaso nas ruas de Paris. Essa disponibilidade "transformada 13 A partir de Freud, o corpo que se inscrevia na tradição filosófica metafísica como o reverso do princípio fundador, a alma, é abalado. A dicotomia metafísica clássica entre corpo e alma é reformulada a partir do postulado freudiano do inconsciente que demonstra ser impossível distinguir o corporal do psíquico, pois eles estariam articulados, imbricados e interfeririam um no outro. O termo corpo psíquico compreende, portanto, a inexistência do dualismo entre o corpo e o psíquico, o mundo interior e o exterior. 
em valor, signo da disposição de recomeçar a vida a cada dia, já é magia propiciatória" (WILLER, 2008, p.328), ou, no dizer de Michel Carrouges, um sentimento de espera:

Esse sentimento extraordinário de espera, que brilha com todos os fogos no surrealismo e principalmente no pensamento de Breton, é a chave de ouro da liberdade. [...] é já um ato interior, é uma abertura de nossas ligações com as correias de transmissão do determinismo. (Apud WILLER, 2008, p.328)

Essa disponibilidade é a condição sine qua non para o surgimento de algo que vem desestabilizar a vida programada, algo que vem promover uma ruptura no terreno aparentemente linear da vida e, portanto, nos fazer mover para fora da jaula da razão e da lógica, em direção ao maravilhoso ${ }^{14}$ e à liberdade e, portanto, ao encontro de nós mesmos para obtermos a revelação do sentido de nossa vida. Mas o maravilhoso não tem endereço e nem uma "forma" específica. Muitas vezes ele se manifesta por meio das "petrificantes coincidências", como o acaso.

As "petrificantes coincidências" são outras vias por onde se manifesta o maravilhoso e, por esse motivo, são dignas de serem narradas: "não tenho por hábito alardear os momentos nulos de minha vida" (BRETON, 2001, p.21). Dessa forma nasce, com Nadja, um novo tipo de narrativa praticada por Breton, que se opõe à literatura psicológica com fabulação romanesca, que não é nem ficção, nem autobiografia. Fragmentada, "sem ordem 14 A noção do maravilhoso, assim como da flânerie, da errância urbana fazem parte da herança baudelairiana no Surrealismo: "A vida parisiense é fecunda em temas poéticos e maravilhosos. O maravilhoso nos envolve e sacia como a atmosfera; mas não o vemos" (BAUDELAIRE apud WILLER, 2008, p.328). Todavia, coube aos surrealistas tomá-lo como potência transformadora da vida. 
preestabelecida e conforme o capricho da hora que trouxer à tona o que vier à tona" (BRETON, 2007, p.29), calcada em episódios marcantes da vida do poeta surrealista e entremeadas de fotografias e reproduções de documentos para "comprovar" que os fatos narrados estavam engajados na realidade, Nadja (2007) é o relato de um período da vida do seu autor, ou, como preferia Breton, o relato da "verdadeira" vida, ou seja, daquela reencantada pela manifestação do maravilhoso.

Muitas de suas páginas foram dedicadas ao relato desses encontros fortuitos:

No dia da primeira apresentação de Couleur du temps, de Apollinaire, [...] um jovem se aproxima de mim, balbucia algumas palavras e por fim dá a entender que me havia tomado por um dos seus amigos, dado como morto durante a guerra. A conversa terminou por aí. Pouco tempo depois, por intermédio de Jean Paulhan, passei a me corresponder com Paul Éluard, sem que um tivesse a menor ideia da aparência física do outro. [...] Éluard veio me visitar: tinha sido ele quem se aproximara de mim em Couleur du temps. (BRETON, 2007, p.33)

O acaso gera a surpresa e, às vezes, é de caráter insólito; um evento singular que escapa à explicação lógica, racional, mas com aparência de um sinal:

Trata-se de fatos com um valor intrínseco pouco verificável, sem dúvida, mas que, por seu caráter absolutamente inesperado, violentamente incidental, e pelo gênero de associações de idéias [sic] suspeitas que despertam, são um modo de nos fazer passar das filandras à teia de aranha, ou seja, ao que seria a coisa mais cintilante e graciosa do 
mundo [...] trata-se de fatos que, ainda que sejam simplesmente constatados, a cada vez apresentam todas as aparências de um sinal, sem que se possa dizer ao certo que sinal [...]. (BRETON, 2007, p.27)

Em Nadja (2007), o relato desse encontro entre Breton e Éluard é seguido por outros sem que haja uma explicação ou mesmo uma reflexão sobre quais são os possíveis sentidos destes "sinais". Todavia, eles levaram Breton a perceber que tudo neste mundo, nesta vida, está interligado, se comunica e, portanto, a pergunta "Quem sou?" deve vir seguida de uma outra: "com quem ando?". O que segundo o autor "trata-se de fatos que, [...] fazem com que, em plena solidão, eu descubra cumplicidades inverossímeis, que me convencem de minha ilusão toda vez que acredito estar sozinho ao leme do navio." (BRETON, 2007, p.27)

E embora eles nada tenham de sobrenatural, Breton afirma ser deles testemunha assombrada: "Entre esses fatos, dos quais não chego a ser, para mim mesmo, mais do que testemunha assombrada, e outros, dos quais me orgulho discernir as circunstâncias e, de certo modo, presumir as consequências." (BRETON, 2007, p.28)

De todos os encontros casuais relatados em Nadja (2007), houve um capital, o mais desconcertante, o mais perturbador, aquele entre Breton e uma mulher misteriosa, um "gênio livre, algo como desses espíritos do ar que certas práticas de magia permitem fixar momentaneamente, mas jamais submeter" (BRETON, 2007, p.102). E como um espírito do ar, ela vivia sob a ação do "vento do eventual": sem residência fixa, sem emprego fixo, lançada ao acaso (como os dados de Mallarmé) nas ruas de Paris, aberta a todos os tipos de aventura e apagando aquela linha tênue que separa o real 
do imaginário. Seu nome? Ela mesma o escolheu: "Nadja" porque, ela explica, "porque em russo é o começo da palavra esperança, e porque é só o começo dela" (BRETON, 2007, p.66-67). Por um curto espaço de tempo do ano de 1926, Breton deixou-se ser levado, fascinado, pela rede de acasos tecida em torno dessa mulher misteriosa, espécie de encarnação do ideário surrealista, cuja fala e comportamento foram acolhidos pelo poeta como poéticos mesmo quando se via assombrado diante de fatos muito insólitos:

Lá pela meia-noite chegamos às Tulherias, onde ela quer nos sentemos por um momento. Diante de nós derrama-se um chafariz cuja curvatura ela parece acompanhar. "São os seus pensamentos e os meus. Olha de onde eles vêm, até onde se elevam, e como é mais bonito ainda quando caem. Logo em seguida se fundem, se refazem com a mesma força, e recomeça esse arremesso que se despedaça, essa queda...e assim indefinidamente." Fico assustado: “Mas, Nadja, como isso é estranho! Onde é que você foi buscar essa imagem, que está expressa quase da mesma forma num livro que você não pode te conhecido, e que acabei de ler?" (BRETON, 2007, p.82)

Nadja desconhecia o Surrealismo, mas vivia, falava, desenhava como uma surrealista. Breton tomou-a como a própria encarnação das aspirações do movimento.

Somente no ano de 1937, em Amor Louco (1971), Breton buscou uma explicação materialista para as "petrificantes coincidências". Compreende o acaso como uma coincidência excepcional entre a necessidade natural e a do desejo humano; ele passa a ser chamado de acaso objetivo "visto que se passa como se a subjetividade (desejante) da pessoa envolvida de projetasse num objeto" 
(CHENIEU-GENDRON, 1992, p.93). A novidade consiste no fato de que o sistema causal efetivado no acaso objetivo concebe uma parte essencial ao inconsciente e à sua assunção pelo imaginário; essa noção implica em correr o risco do trágico se se quer assumir o próprio desejo (CHENIEU-GENDRON, 1992, p.94). Quando Breton elucida a noção de acaso objetivo, descobre a "lei" misteriosa de intercâmbio entre a matéria e o espírito: o desejo inconsciente.

A disponibilidade e a flanerie nos colocam à disposição do acasoobjetivo; ele, por sua vez, desvela a relação mágica entre a poesia e vida e, portanto, nos permite ir ao encontro do maravilhoso:

O acontecimento que cada de nós está no direito de esperar que seja a revelação do sentido da sua própria vida, [...] não virá ao preço do trabalho. Mas me antecipo, pois talvez seja aqui, [...] o que a seu tempo me fez entender e o que justifica, [...] a entrada em cena de Nadja. (BRETON, 2007, p.62)

Mas a revelação da qual o caso objetivo pode ser o portador só ocorre mediante sua transcrição escrita ou oral. A escritura não é contemporânea aos fatos narrados, mas contemporânea à sua interpretação, ao seu deciframento, explica Chenieux-Gendron (1992, p.94). $O$ ato de narrar é a forma de objetivar o que é subjetivo e ao realizá-lo é possível estabelecer correspondências, associações livres entre fatos distantes e atribuir-lhes um sentido, revelação equivalente àquela que ocorre por meio da escrita automática. A narrativa dos acasos objetivos em Nadja (2007) permite a Breton solucionar a questão: “Quem sou?" (BRETON, 2007, p.21). Contudo,

a revelação de quem somos exige que a linguagem e a imaginação estejam submissas ao desejo, na perspectiva de que este se manifeste por meio do 
outro, que vem nos dizer quem somos por meio de uma linguagem que não é a habitual, mas a linguagem a enigmática, que revela a vocação mesma da linguagem, que é ser oracular. (DANTAS, 2008, p.101)

Assim foi a entrada de Nadja na vida de Breton, ela permitiu a ele descobrir sua singularidade. Sua fala desarrazoada descobre o outro que é Breton. Sua linguagem se mostra absolutamente oracular; ela "prevê o livro que ele escreveria sobre ela; lê, nos sinais impressos na sua vida, seu fim trágico [...]: 'O fim de minha inspiração, que é o começo da tua'"' (DANTAS, 2008, p.102). Nadja é aquela que lança a esperança embora não possa realizá-la. Ela é o "começo da esperança de Breton no amor, na mulher e na beleza - que só pode ser convulsiva" (DANTAS, 2008, p.101-102); começo porque ela preanuncia a entrada, na vida de Breton, de outra mulher.

A necessidade da simbiose do escrito e com o vivido sempre foi reafirmada pelos surrealistas em contraponto à profissão do escritor. E no período em que Breton escreve Nadja (2007), ele concebe a escrita como um meio que aponta para soluções particulares para os problemas da vida.

Em Nadja (2007), o imaginário e o real, o passado e o futuro, o comunicável e o incomunicável, o consciente e o inconsciente não são mais percebidos como coisas contraditórias. O maravilhoso se manifesta como raios que abrem enormes crateras no tecido liso, da realidade e fazem jorrar uma ordem até então oculta; é um "apelo ao surreal, uma incitação a ver o surreal no real, em outras palavras, a ter um olhar ativo sobre o mundo" (SANGOUARD, 2010, p.3). 


\section{O MARAVILHOSO: UM INSTANTE PERTURBARDOR}

A comunicabilidade do maravilhoso é condição necessária para sua plena realização. Como nas práticas de magia, as palavras têm um papel decisivo no processo de reencatamento do mundo e na transformação da vida: "Não é necessário modificá-las [...]. Basta que nossa crítica recáia [sic] sobre as leis que regulam o seu conjunto. A mediocridade de nosso universo não depende de nosso poder de enunciação? " (BRETON, 1970, p.22)

$\mathrm{O}$ ato de narrar as experiências em que os raios do maravilhoso atingem a vida é também ultrapassar a experiência individual em direção à coletiva; é incitar outros homens e mulheres a se lançarem às ruas e a estarem abertos para perceber sua manifestação nas coisas banais do cotidiano.

Na busca dos surrealistas pela liberdade, pela emancipação total do homem, a literatura, que disponibiliza a linguagem a serviço da imaginação criadora, desempenha um papel muito importante porque, pensava Breton, a potência da linguagem alteraria a própria vida na medida em que ela não mais representaria o real, mas construiria-o, na sua amplitude, borrando os limites entre o mundo interno e o externo.

O homem, para o Surrealismo, é ele mesmo uma fronteira consciente entre esses dois mundos: aquele exterior e limitado e aquele interior, múltiplo e ilimitado. 0 maravilhoso é a possibilidade de contato entre esses dois mundos. Ele "aproveita os pontos de fraqueza da inteligência organizadora, e como o fogo de um vulcão, se insinua entre as falhas das rochas; ele ilumina os celeiros da infância; ele é a estranha lucidez do delírio; é a luz do sonho" 
(MABILLE, 1946, p.69). O maravilhoso é o magma flamejante pulsando no centro da revolta, é a tensão extrema do ser no momento do encontro do desejo inconsciente com a realidade exterior. Ele é «um momento preciso, um instante perturbador onde o mundo nos dá seu acordo» (MABILLE, 1946, p.69).

\section{REFERÊNCIAS}

BAUDELAIRE, Charles (1988). A modernidade de Baudelaire. Apresentação de Teixeira Coelho; Suely Cassal (Trad.). Rio de Janeiro: Paz e Terra.

BÉHAR, Henri (1999). "Le merveilleux dans le discours surréaliste, essai de terminilogie”. In: Revue Mélusine n²0: Merveilleux et surréalisme. Chaiers du Centre de Recherche sur le Surréaliste. Lausanne: L'Age d'Homme. p.15-29.

BONNET, Marguerite (1975). André Breton: naissance de l'aventure surréaliste. Paris: Librarie José Corti.

BRETON, André (1970). "Introduction au discours sur le peu de réalité". In: Point du jour. Paris: Gallimard. p.7-29.

(1971). O amor louco. Luiza Neto Jorge. Lisboa (Trad.). Editorial Estampa. (1979a). "Le merveilleux contre le mystère". In: La clé des champs. Paris: Société Nouvelle des Éditions Pauvert. p.7-13.

(1979b). “Limites non-frontières du surréalisme”. In: La clés des champs. Paris: Société Nouvelle des Éditions Pauvert. p.14-28.

(1979c). "L’art des fous, la clé des champs". In: La clés des champs. Paris: Société Nouvelle des Éditions Pauvert. p.274-278.

(1988). "Les chants de Maldoror". In: Oeuvres completes I. Paris: Gallimard. p.233-235.

(2001). Manifestos do Surrealismo. Sergio Pachá (Trad.). Rio de Janeiro: Nau Editora.

(2007). Nadja. Ivo Barroso (Trad.). São Paulo: Cosac Naify.

CHÉNIEUX-GENDRON, Jacqueline (1992). O Surrealismo. Mário Laranjeira (Trad.). São Paulo: Martins Fontes. 
(2014). Inventer le réel: le surréalisme et le roman. Paris: Honoré Champion Éditeur.

COLLANI, Tania (2007). "Le merveilleux surréaliste de Michel Leiris et la conciliation avec la modernité". In: Revue Cahiers Leiris n.2. Mercourt: Editions Les Cahiers, novembre. p.22-37.

DANTAS, Marta (2008). "Breton: um errante sonhador". In: SANTOS, Volvei Edson dos (Org.). Sopros do silêncio. Londrina: EDUEL. p.71-105.

LIMA, Sérgio (1995). A aventura surrealista. Campinas: Ed. UNICAMP; São Paulo: Ed. UNESP; Rio de Janeiro: Vozes.

MABILLE, Pierre (1946). Le Merveilleux. Paris: Les Éditions des Quartre Vents. (2002). "Le Miroir du merveilleux. Sagitaire, 1940, repris aux éditions de Minuit, 1962, p.28-33". In: CHÉNIEUX-GENDRON, J. (Org.). II y aura une fois: une anthologie du Surréalisme. Paris: Gallimard. p.228-231.

MORRIER-CASILE, Pascaline (1994). Nadja d'André Breton. Paris: Gallimard. NATSUME-DUBÉ, Sachiko (1995). "Du Merveilleux surréaliste au Merveilleux realiste: l'évolution de la notion du merveilleux chez Michel Leiris". Kyoto: Kyoto University. p.107-126. In https://repository.kulib.kyotou.ac.jp/dspace/ bitstream/2433/137828/1/fbk000_026_107.pdf Acesso em 10.Ago.2017.

PESSANHA, J. A. M. "Bachelard: as asas da imaginação". In: BACHELARD, G. $O$ direito de sonhar. Rio de Janeiro: Bertrand do Brasil, 1994, p.5-31.

SANGOUARD, Céline (2010). "Le merveilleux est toujours beau, n'importe quel merveilleux est beau, il n'y a même que le merveilleux qui soit beau". In: Acta Fabula, Revue de Parutions, juin. In http://www.fabula.org/acta/document5795. php Acesso em 10.Ago.2017.

TODOROV, Tzvetan (2014). Introdução à literatura fantástica. Maria Clara C. Castello (Trad.). São Paulo: Perspectiva.

WILLER, Claudio (2008). "Magia, poesia e realidade: o acaso objetivo em André Breton". In: GUINSBURG, J.; LEIRNER, S. (Org.). O Surrealismo. São Paulo: Perspectiva. p.323-350.

(2008) "Escrita automática: uma falsa questão?" In: GUINSBURG, J.; LEIRNER, S. (Org.). O Surrealismo. São Paulo: Perspectiva. p.709-722. 